\title{
Developing Anti Hoax Competency of Teenagers Through Critical Thinking Practice: An Action Research
}

\author{
A R L Teluma ${ }^{1}$, S D Fajarica ${ }^{2}$, A P Hadi ${ }^{3}$, \\ N Maulida ${ }^{4}$ \\ 1,2,3,4 Universitas Mataram, Indonesia \\ 1aureliusteluma@unram.ac.id, ${ }^{2}$ shintadesiyana.f@unram.ac.id, ${ }^{3}$ aguspurbathin@gmail.com \\ ${ }^{4}$ oppietaa@gmail.com
}

\begin{abstract}
Hoax is the enemy of digital contemporary socio-economic and socio-cultural systems development. Among the Indonesian netizens, teenagers is one of active internet users. So, it is important to make them have the complete anti hoax competency that includes cognitive, affective and psychomotor aspects. This study aims to improve the anti hoax competency of adolescents. This research method is modified action research based on critical thinking practice. The participants were 40 students of SMAN 1 Sakra, East Lombok Regency, Indonesia. Data were generated by a set of self-assessment questionnaires and an assessment of the results of the training in differentiating news vs. views.
\end{abstract}

Keywords: Anti hoax competency, Teenagers, Critical Thinking Practice, Action Research

\section{INTRODUCTION}

Providing Indonesian teenagers with the ability to have critical thinking competencies is a very crucial mission amid hoaxes spreading within the internet. However, according to data wearesocial.com, adolescence is the second largest internet users in Indonesia. Thus, most youth who are potentially exposed to a variety of false information or hoaxes.

Why not, according to survey results Indonesian Telecommunications Society (Masyarakat Telekomunikasi Indonesia) in April 2019, a total of $34.60 \%$ of netizens in Indonesia received a hoax news every day. Similarly, the results of the analysis of the Indonesia Ministry of Communication and Information Technology (Kominfo) in the first two months in 2019 show that during the month of January 2019 there were 175 issues hoax, and 2 weeks of the beginning of February 2019 there were 96 issues a hoax. The amount is of course only part of the issue of hoaxes circulating in Indonesia because the reported netizens are just simply that can be monitored by the Communications and Information Technology Ministry based on the reports public.

Massive spreads of the hoax can harm the solidarity of social life. The research results Vosoughi et al (2017) from MIT Initiate on the Digital Economy shows that the spread of fake news is faster, deeper and further than news that is true according to the credible mass media[1]. Based on the analysis of the distribution of false news through Twitter in 2006 2017, Vosoughi et al. [1] get the fact that the false news has a greater chance of $70 \%$ to 
retweet than the correct news $(30 \%)$. Therefore, it is necessary to develop the ability of youth to turnback hoax systematically and comprehensively.

Formally, there are three important approaches needed to anticipate the hoax news spread in society that an institutional approach, technology, and literacy[2]. Institutional approach, the community continues to promote anti hoax. Technology approach, with Checker hoax application that can be used by the public to check the truth of news which indicates a hoax. The literacy approach, with the anti-hoax news and dissemination to the public from the school to the public, enhanced and encouraged, not only by the government but by the whole society including non-governmental institutions more.

Meanwhile, when the existence of gadgets simplifies the production and dissemination of contents hoax, the High School teens are not equipped specifically on how to recognize, identify and hoaxes. In the schools, the density of lessons have been scheduled to make the teens are rarely studied beyond the knowledge of other subjects. Though dealing with a hoax, in addition to aspects of knowledge (cognitive) and affective be strengthened but also the skills to use the various tools that are available free of charge to obtain information about the real thing. Based on the massiveness hoax phenomenon that has great potential to influence attitudes and behavior of adolescents both quantitatively and qualitatively, as described above,

The ability to ward off this hoax be referred to as "anti hoax competence" because anti hoax includes not only the technical aspects of the motor or the issue of the use of gadgets but also critical thinking and emotional maturity in managing information. In the context of pedagogy, referring to Law No. 20/2003 on the Indonesian National Education System explanation of article 35, paragraph 1 , the competence of a person's ability qualifications that include attitudes, knowledge, and skills by national standards that have been agreed. In short, competence is the integration of knowledge, skills, and attitudes that enable them to carry out an effective way. Then anti hoax competence can be defined as the integration of knowledge, skills, and attitudes to recognize and counter effectively hoax.

As a capacity cognitive, affective, conative or psychomotor then anti hoax competence not only introduced but also the foremost are trained constantly in order to increase. Thus, a study of the ability of anti hoax on teenagers and other groups should be intervention, not just socializing. Operationally, the cognitive, anti hoax competencies related to knowledge and understanding of the characteristics of false news vs. news is true. On the affective aspect, anti hoax competence relating to the management of emotions and attitudes when dealing with news or information which is not known the truth even if derived from the elder person or trusted. On the psychomotor, the youth have the skill to use the hoax buster tools.

The first step to establish and build competencies of anti hoax is by developing critical thinking skills. The concept of critical thinking can be expressed in a variety of definitions, depending on one's purpose (though, as with every concept, its essence is always the same). Critical thinking is the process of analyzing and assessing thinking in order to improve it. Critical thinking presupposes the knowledge of the most basic structures of thought (elements of thought) and the most basic intellectual standards of thought (universal intellectual standards) [3].

\section{RESEARCH METHOD}

This study conducted by Kemmis and Mc Taggart (2000) Model of Action Research which implies the process of planning, acting, observing and reflecting in analyzing the tested concept[4][5]. Firstly, at the planning stage, any observed changes were initiated prior to the implementation. Next, the consequences of the implementation were observed. Last but not 
least, reflection was made to unleash the results. However, if the result did not meet the targeted objective, re-planning was to be considered.

Action Research is the research conducted collaboratively by the participants in the social sciences and education to improve the understanding and implementation of the work itself, and also had an impact on the surrounding environment. In short, an action research study designs that aim to describe, interpret and explain a social situation at a time to make changes or interventions to repair or participation of the situation.

The participants were 40 students of SMAN 1 Sakra, East Lombok, West Nusa Tenggara (NTB) which consists of 24 students and 16 students who actively participate in the Anti hoax Literacy Digital Workshop on July 2019 carried out by community service team of communication science department of Mataram University.

Data were generated self-assessment questionnaires and assessment sheets of products which includes three aspects namely competence cognitive, affective and psychomotor. Each indicator is weighted items 1-4 in the Likert Scale. In detail, aspects and indicators in each aspect outlined in Table 1.

Table 1. Aspects and Indicators Competence Antihoax

\begin{tabular}{cll}
\hline N. & \multicolumn{1}{c}{ Aspect } & \multicolumn{1}{c}{ Indicator } \\
\hline 1 & Cognitive aspects & $\begin{array}{l}\text { Read and understand the entire contents of } \\
\text { the news }\end{array}$ \\
\cline { 3 - 3 } & Affective aspects & $\begin{array}{l}\text { Have the knowledge abou one / several } \\
\text { applications hoax checker online }\end{array}$ \\
& $\begin{array}{l}\text { Do not think you should be the first to share } \\
\text { the news that has not been true }\end{array}$ \\
\cline { 3 - 3 } & Psychomotorics Aspects & $\begin{array}{l}\text { Fixed confirm the sender of the message, } \\
\text { even from parents / elders }\end{array}$ \\
& $\begin{array}{l}\text { Search for and read another news source for } \\
\text { comparison }\end{array}$ \\
\cline { 3 - 3 } & $\begin{array}{l}\text { Using a hoax application checker to verify } \\
\text { information }\end{array}$ \\
\hline
\end{tabular}

The data were analyzed using descriptive statistical analysis to see differences in the results obtained by the students in each cycle. Calculations, the acquisition score divided by the maximum score every aspect of every aspect $(40 \times 4=160)$ multiplied by the maximum value (4). While the assessment guidelines and categories of test results adjusted for completeness assessment guidelines and manifested in a predicate as listed in Table 2.

Table 2. Range of Values and Criteria

\begin{tabular}{ll}
\hline Range of Values & Criteria \\
\hline 3.51 to 4.00 & Very good \\
\hline 2.51 to 3.50 & Well \\
\hline 1.51 to 2.50 & Enough \\
\hline 1.00 to 1.50 & Less \\
\hline
\end{tabular}




\section{RESULTS AND DISCUSSION}

Design or planning of this cycle include: 1) pretest activities anti hoax competency mapping using self-assessment questionnaire (self-assessment); 2) intervention in the form of socialization hoax definition, types and distribution; 3) The second intervention in the form of exercises distinguish news vs. views of online news script; 4) post-test using an instrument similar self-assessment and assessment on the results of distinction news products vs. views of a news article in the online media. The value of these instruments and its average to obtain the final value of each aspect of results obtained in the first cycle illustrated in Figure 1.

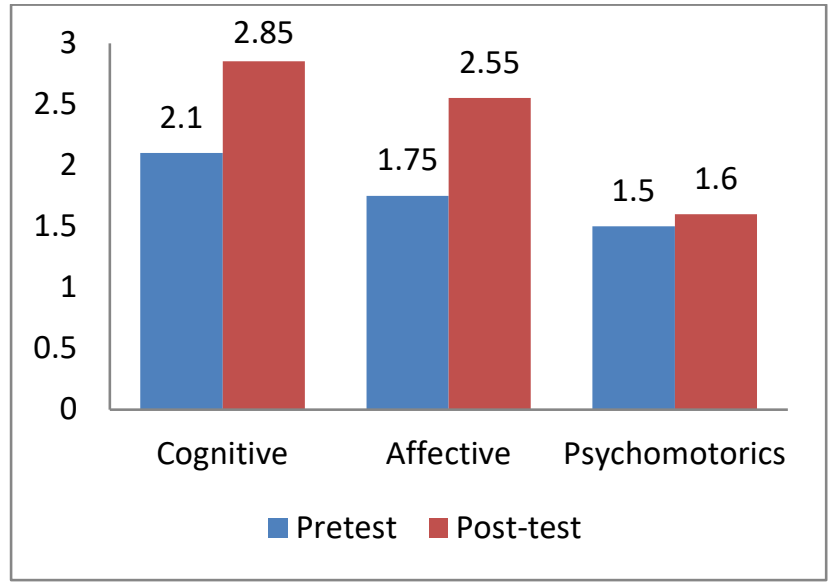

Diagram 1. The results of self-assessment and test execution cycle

Diagram 1 shows that at pretest, anti hoax competence on cognitive aspects that are in both categories (2.10) and increased though still in the same category at the end of the action with the acquisition value of 2.85. On the affective aspect, the pretest score anti hoax competency assessment is in the category Self (1.75) and increased to a category Good (2.55) on a post-test assessment. Lastly, the psychomotor, a pretest assessment results are included in the category of Less (1.50) and then increased to a category Enough on assessing post-test (1.60).

The test results based on the research design above actions demonstrate and reinforce the idea that the ability to ward off a hoax or fake news is a competence that covers the whole human dimension of cognitive, affective and psychomotor. Barth et al. characterised competencies as dispositions to self-organisation, comprising different psycho-social components, existing in a context-overlapping manner, and realising themselves contextspecifically [6]. So that, by increasing the anti hoax competencies, the teenagers have the sustainable learning resources to turning back the hoax [7].

The research results Feldman et al.[8] which showed a strong relationship between attitudes toward a lie or a hoax by psychological factors such as the level of self-confidence, showing how the capacity to ward off a hoax for individual digital age is a matter that goes beyond technical skills alone. Therefore, as a competency, then practice and practice constantly and effectively is a strategic step for forming individuals capable of effectively counteracting hoax.

The existence of youth as the digital generation (digital native) made after the group became the largest users of social media. Meanwhile, at the same time, psychologically it is youth ages who are looking for identity that are vulnerable to a variety of social influence in 
the vicinity. Research conducted by Feldman [8] and his colleagues, a psychologist at the University of Massachusetts shows that the lie has associated with self-confidence. When confidence is threatened someone would easily lie. At least 60 percent of the people who researched by Feldman is lying in every conversation is done. It is also common on the internet, a person often adds to the news that is uncertain to lie so as to produce a hoax chain.

The approach makes anti hoax as competencies are trained in structured or pedagogical action is rarely carried out in research stubs hoax. Some research in Indonesia about the hoax centered on the effects of hoax against the socio-political life and democracy and how to overcome the institutional both state and media institutions [2][9] as well as the mapping of patterns and shapes hoaxes [10]. Other research is quite close as the education and cultivation of the ability to fight hoax but still socialization and creative response through expressive art media and multimedia [11][12].

Faced with hoaxes, the competencies required antihoax competence is not a "mediocre" but critical. Therefore, in addition to knowledge, affective and psychomotor, formation and training of critical thinking skills is central to be supplied. Research Changwong et al [13] showed that there is a correlation between the development of critical thinking with the ability to learn and readiness to learn at the next level of high school students in Thailand. Students are given a critical thinking exercise more readily than the group who were not given the intervention in the form of critical thinking exercises. In the digital society context, developing information literacy and critical thinking skills through domain knowledge learning in the classrooms process can make the teenagers be literate and thinking critically [14]. A critical thinking course for assessing the fake news must be the part of pedagogical process [15].

In the context of detecting hoaxes, exercise critical thinking skills could begin by mastering one of knowledge and skills in the field of journalism that distinguishes news items of the opinions or views. News is a report or presentation that will be factual events, actual and interesting or appropriate public interest, while the views are opinions, views or opinions about an issue, event or occurrence. News and views are the two elements forming the content of journalism. Nevertheless, to journalistic work actually contains the correct information and credible than these two elements must be proportionate and reasonable and by following the interests and the public good.

Hoax information that is engineered to cover the actual information. In other words, hoaxes can also be interpreted as an attempt to manipulate fact use the information as if reassuring but not verifiable truth. Hoax can also be interpreted as an act obscure factual information, by flooding the media with a wrong message in order to cover up the correct message. The purpose of deliberate hoax is to make people feel unsafe, uncomfortable, and confusion. In the confusion, the public will decide who is weak, unconvincing, and even wrong. Developments in social media hoax was originally performed for destructive means. However, subsequent developments,

Strong and complex hoax destructive force for the public, including young people who are in search of identity with the level of knowledge and life experience, is not adequate, it makes repeated practice to have anti hoax competency is necessary to be encouraged.

\section{CONCLUSIONS}

Hoax may adversely affect the social, economic, political and cultural community, including the contemporary digital economy. Especially, the youth of today is the heirs of the digital society that is being fought at once the most vulnerable groups exposed to various impacts hoax. To that end, the teens really need to be educated and trained to be able to 
effectively counteract hoax. The youth must have the competency of anti hoax. Anti hoax competence can be formulated, trained and improved through practice-based action research, critical thinking. This is evident from the results of the action research on adolescent of SMA Negeri 1 Sakra, East Lombok, West Nusa Tenggara.

This study has limitations either on the number of samples or completeness of the research instruments once intervention instruments, especially the lack of training and measurement of hoax checker application usage. To that end, the study further action to complement the instrument on every aspect in order to increase the competence anti hoax can be achieved optimally.

\section{REFERENCES}

[1] S. Vosoughi, R. Deb, and S. Aral, "The Spread of True and False News Online. MIT Initiative on the Digital Economy Research Brief," Science (80-. )., vol. 359, no. 6380, pp. 1146-1151, 2018.

[2] C. Juditha, "Hoax Communication Interactivity in Social Media and Anticipation (Interaksi Komunikasi Hoax di Media Sosial serta Antisipasinya)," J. Pekommas, vol. 3, no. 1, p. 31, 2018.

[3] R. Paul and L. Elder, "Critical thinking competency standards," Found. Crit. Think. Press. ..., 2007.

[4] M. Gaffney, "Participatory Action Research: An Overview--What Makes It Tick?.," Kairaranga, vol. 9, no. 1986, pp. 9-15, 2008.

[5] S. Cronholm and G. Goldkuhl, "Conceptualising participatory action research three different practices," Electron. J. Bus. Res. Methods, vol. 2, no. 2, pp. 47$58,2003$.

[6] M. Barth, J. Godemann, M. Rieckmann, and U. Stoltenberg, "Developing key competencies for sustainable development in higher education," Int. J. Sustain. High. Educ., vol. 8, no. 4, pp. 416-430, 2007.

[7] N. Giangrande et al., "A competency framework to assess and activate education for sustainable development: Addressing the UN sustainable development goals 4.7 challenge," Sustain., vol. 11, no. 10, pp. 1-16, 2019.

[8] B. R. Feldman, Robert S.; Forrest, James A.; Happ, "Self-Presentation and Verbal Deception: Do Self- Presenters Lie More?," Basic Appl. Soc. Psych., no. November 2002, pp. 37-41, 2002.

[9] A. N. Desga, "Upaya Media Massa Online dalam Menghadapi Berita Hoax," J. Kaji. Media, vol. 2, no. 2, pp. 97-101, 2018.

[10] D. R. Rahadi, "Perilaku Pengguna Dan Informasi Hoax Di Media Sosial," J. Manaj. Dan Kewirausahaan, vol. 5, no. 1, pp. 58-70, 2017.

[11] Y. D. Astuti, "Peperangan Generasi Digital Natives Melawan Digital Hoax Melalui Kompetisi Kreatif," Informasi, vol. 47, no. 2, p. 229, 2017.

[12] G. E. Saputro and T. Haryadi, "Edukasi Kampanye Anti Hoax Melalui Komik Strip,” Desain Komun. Vis. Manaj. Desain dan Periklanan, vol. 3, no. 02, p. 94, 2018.

[13] K. Changwong, A. Sukkamart, and B. Sisan, "Critical thinking skill development: Analysis of a new learning management model for Thai high schools," J. Int. Stud., vol. 11, no. 2, pp. 37-48, 2018.

[14] S. C. Kong, "Developing information literacy and critical thinking skills through domain knowledge learning in digital classrooms: An experience of practicing 
flipped classroom strategy," Comput. Educ., 2014.

[15] D. W. Chambers, "Lessons from students in a critical thinking course: A case for the third pedagogy," J. Dent. Educ., vol. 73, no. 1, pp. 65-82, 2009. 